Joanna Rosak-Szyrocka ${ }^{l}$

\title{
HUMAN RESOURCES MANAGEMENT IN IMPROVEMENT ASPECT
}

\begin{abstract}
Quality Systems ensure improvement in the quality and safety of medical services, as well as provide greater predictability and stabilization of the processes realized in health care. The aim of the paper is to present the role of quality management systems in competitiveness aspect as well as quality of hospitals in Poland as well the patient satisfaction was evaluated basis on Servqual method.
\end{abstract}

Key words: quality systems, satisfaction, client/patient, human resources, health care.

\section{Introduction}

Human resources (immaterial) these are workers about the various level and the kind of education, the gender, the cover, people coming from various professional environments and political (JANUSZ S. 2003, JURKOWSKI 2002). THE worker is the internal customer of the organization and therefore it is necessary to look after his planes carefully, as for the outside customer. Care of the worker should embrace (BORKOWSKI S., ROSAK-SZYROCKA J. 2012, BORKOWSKI S., ROSAKSZYROCKA J. 2010):

- method of behaviour towards internal and outside customers,

- preparing the profitable climate, the workers' community.

Personnel is considered for the most important resources of the organization because:

- efficiency of working the organization is starting with the quality of it's workers' work that have impact their talent, education, skills,

\footnotetext{
${ }^{1}$ Institute of Engineering Production, Faculty of Management, Czestochowa University of Technology, e-mail: asros@op.pl.
} 
experience, purposes and values, attitudes and behaviours, features of the personality and motivations,

- problems are being solved thanks to personnel in the organization,

- it is a strategic resource, able at learning and the improvement in one's potential, able at conceptive thinking resource, as well as creative.

In popular feeling of medical environment, shared by persons from other professional environments, the level of doctors' payment in the Polish health care system is no adequately that has influence for the satisfaction at executed work. A form of employment doctors' on vacancies was pervading among doctors in public centers of the health care until the end of 80 years. Diversity the level of income each social group was occurring within 90 years. Representatives of competition requiring high specialized competence began to obtain higher payment: lawyers, economists, computer scientists and various engineering competition.

In popular feeling environments, medical doctors were excluded from this process, to a considerable degree from the reason of obtaining the majority one's profits on the public health care sector. Clients/patients feeling authorized to obtain provisions about various type, supported by social and political environments in this conviction, as well as informed of the newest achievements of medicine in the world, are expressing bigger and bigger dissatisfaction from the activity of the system. Workers of the health care sector are being subjected to financial limitations and the constant pressure for increasing the range and the volume of services.

The main aim of the paper was to evaluate patients' satisfaction from medical services by Servqual method. The research object were public hospitals located in different area of Poland, possesses different reference level. The paper presents methods of improvement medical services by quality systems like accreditation, ISO 9001. 


\section{Human resources management at hospital}

Clients/patients feeling authorized to obtain previsions about various type, supported by social and political environments in this conviction, as well as informed of the newest achievements of medicine in the world, are expressing bigger and bigger dissatisfaction from the activity of the system. Workers of the health care sector are being subjected to financial limitations and the constant pressure for increasing the range and the volume of services.

Doctors are limiting or they are quitting practices in the public sector as a result, moving their activity to the private sector, financed by clients/patients directly. Customers'/patients' huge part searching for the medical assistance and no becoming reconciled for limitations and often low standard of the public sector services, is proceeding to the private sector too (ROSAK-SZYROCKA, 2007). Figure 1. shows the number of doctors in selected years in Poland.

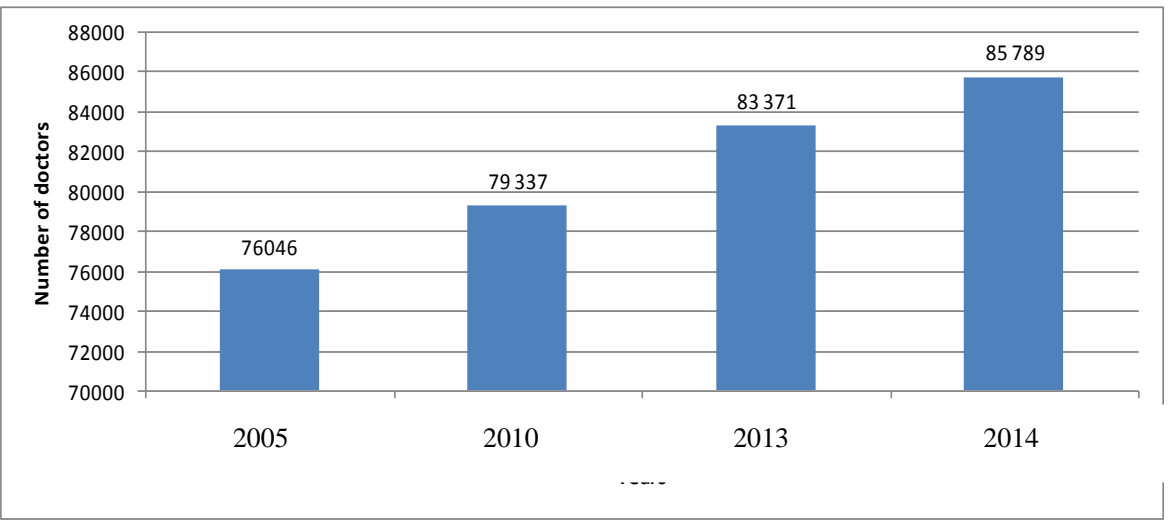

Fig. 1. The number of doctors in selected years in Poland. Source: own study basis on: Statistical Bulletin of the Ministry of Health 2015

A report published in 2010 by the Organization for Economic Cooperation and Development (OECD), which brings together 33 highly developed and democratic countries in 2008 in Poland accounted for 2.2 
statistically practitioner per 1,000 inhabitants, well below the average in OECD countries, which is 3.2 . Larger disparity relate to the number of nurses. In Poland there are 5.2 per 1,000 inhabitants, while the average in OECD countries - 9. Figure 2. shows the number of nurses in selected regions in Poland.

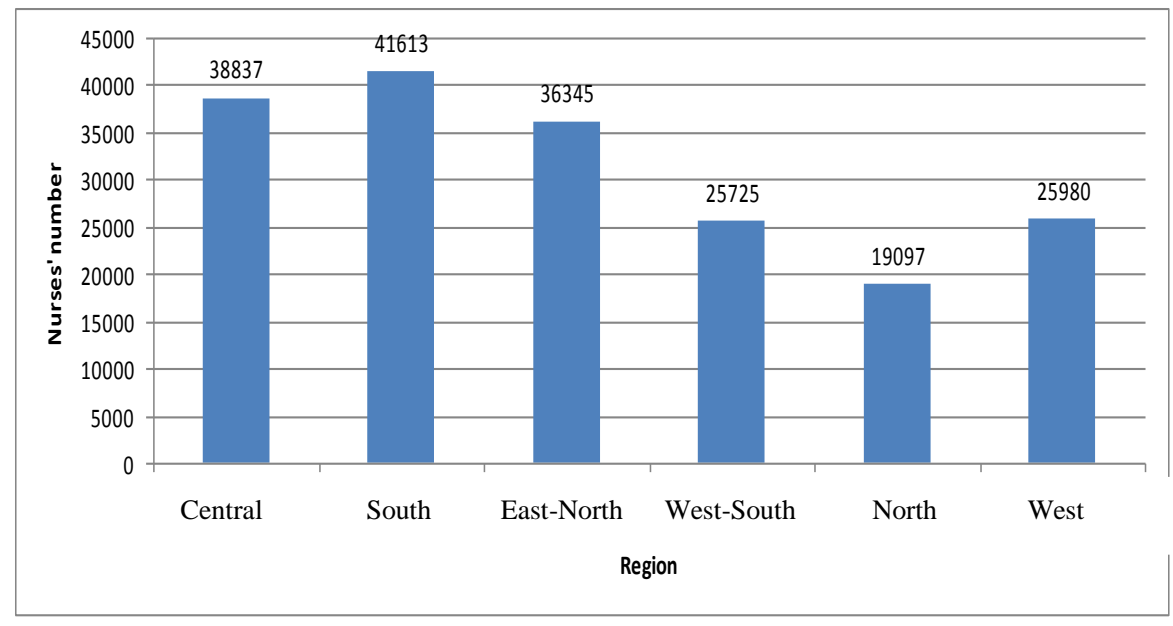

Fig. 2. The number of nurses in chosen regions. Source: own study basis on: Statistical Bulletin of the Ministry of Health 2015

\section{Clients'/patients' satisfaction analysis}

Clients'/patients' satisfaction analysis was evaluated basis on Servqual method. Using the method Servqual service providers can anticipate customer expectations and identify the level of assessment of their services by recipients. Servqual used to verify the quality assessment. Studies assessing the quality of fixed-line medical care based on the following formula:

$$
S=P-O
$$

where: $\mathrm{S}$ - the result Servqual, 
$\mathrm{P}$ - perception of the service by patients,

$\mathrm{O}$ - patient expectation of service.

Servqual (an acronym derived from the term „Service Quality ${ }^{\text {(e) }}$ is a well tested survey method for measuring service quality which focuses on five service quality dimensions. Servqual surveys usually include 22 service areas distributed throughout the five service quality dimensions.The survey often asks the customers to provide two different ratings on each attributeone reflecting the level of service they would expect from excellent companies in a given sector and the other reflecting their perception of the service delivered by a specific company within a sector. The difference between the expectation and perception rating constitutes a qualified measure of service quality (TAZREEN, 2012). The sample was 1200 hospital patients in Poland. Figure 3 shows the evaluation Servqual of the result from the patients point among hospitals having and not having quality systems. Analysis figure 3 shows that among the 30 research facilities have quality management systems in one case, patients' expectations have been greatly exceeded $\mathrm{P}>\mathrm{O}$ ( ideal state). This is the case in 36 hospital possessing II level reference, where the outcome $\mathrm{S}=$ 0.17 . Analysis of the remaining 13 research facilities with quality management systems, allows concluded that expectations for quality are not fully satisfied (have a value slightly below the value 0 ). These are the hospitals and the degree of references $(1,2,4,5$ and 7 research facility ) and the second stage reference $(25,27,29,30,39,40,41,42$ research facility ). Moving on to the analysis of institutions that do not have quality management systems, you will see that only 7 research facilities rated as good . Hospitals are both I and II and stage III reference (17, 19 , $22,43,49,53,56$ research facility ). Other institutions have values well below 0 . In the figure 4 was presented number of doctors. The analysis of presented figure shows that the highest number of doctors occurs in the 58 tested hospital (403 doctors) and in the 59 tested hospital (461 doctors). 
Zeszyty Naukowe

No. 2(5)

Quality. Production. Improvement

2016

pp. $105-121$

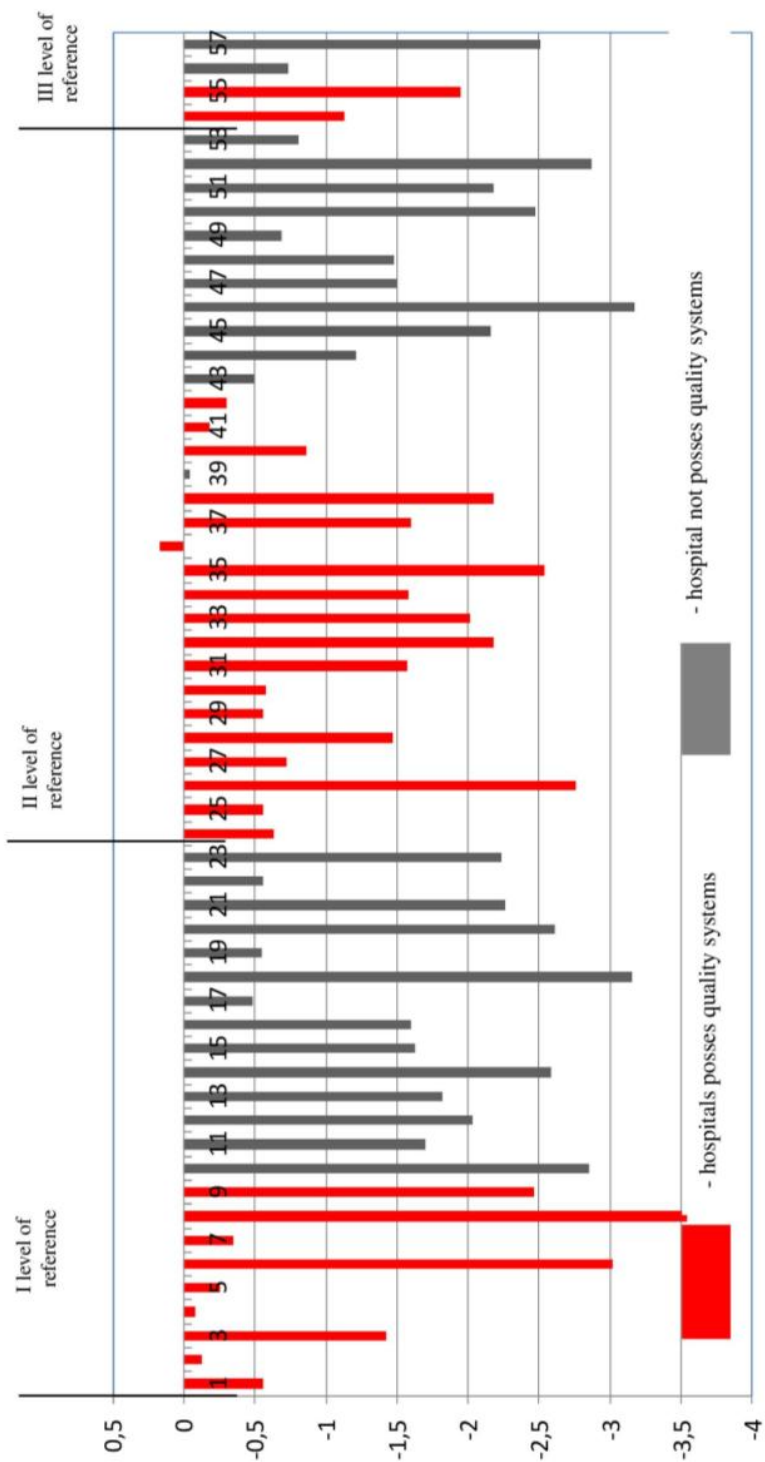

Fig. 3. Evaluation of the quality of medical services for patients and hospitals have not have quality systems.

Source: own study 


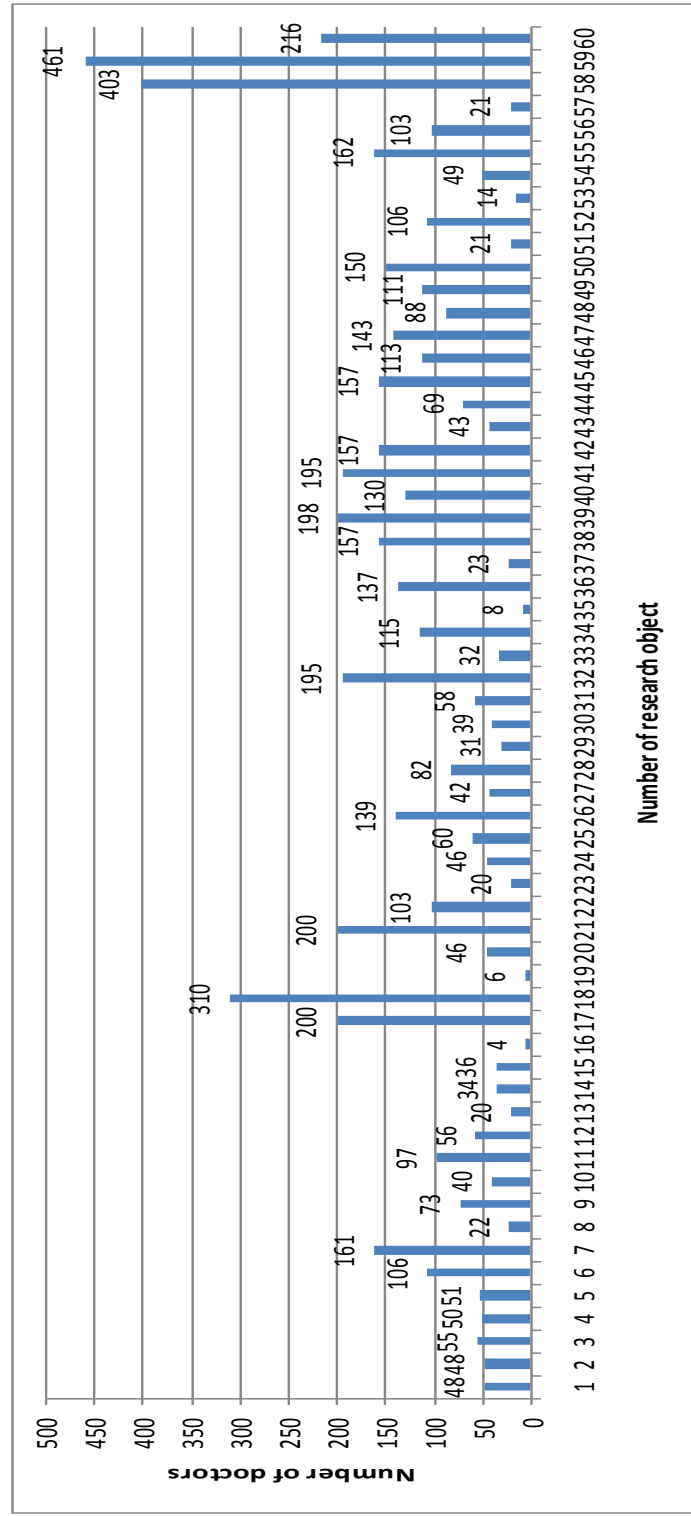

Fig. 4. Number of doctors in research objects.

Source: own study 


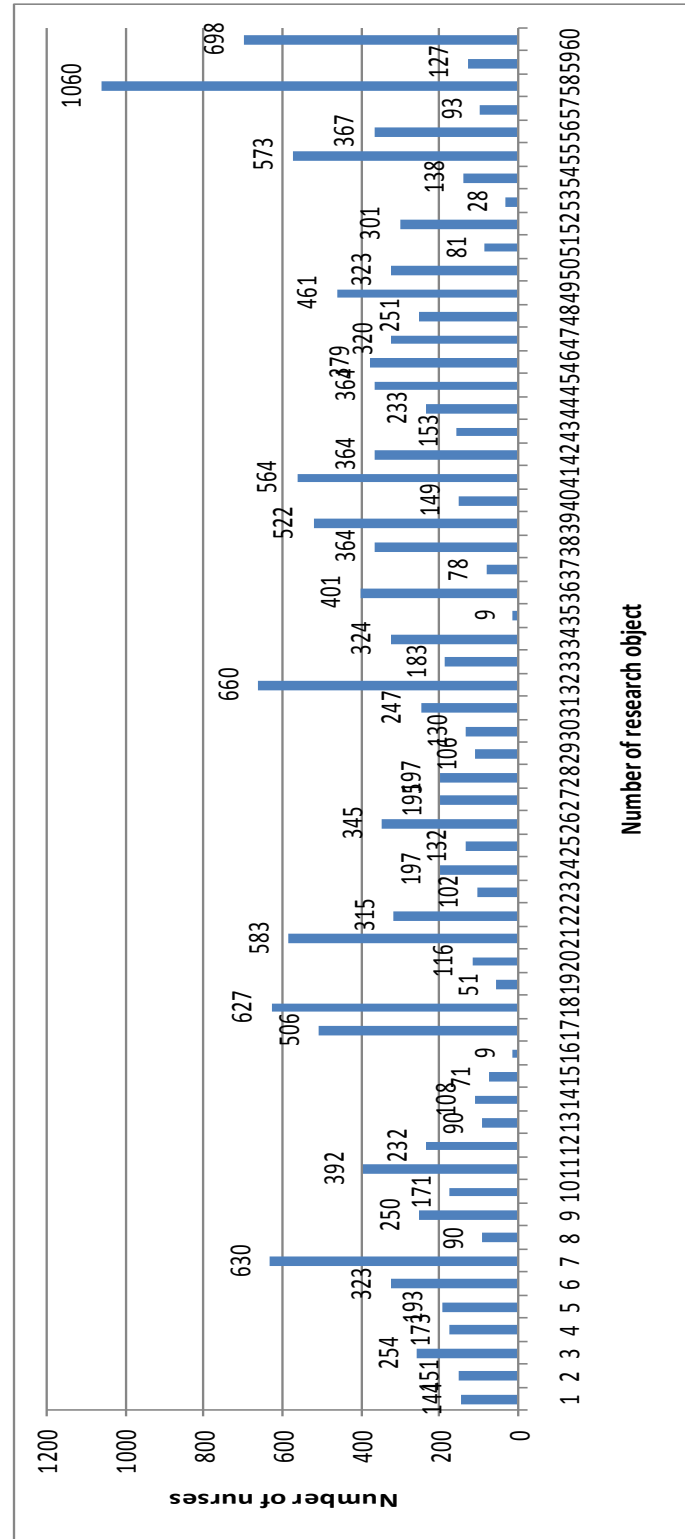

Fig. 5. Number of nurses in research objects.

Source: own study 


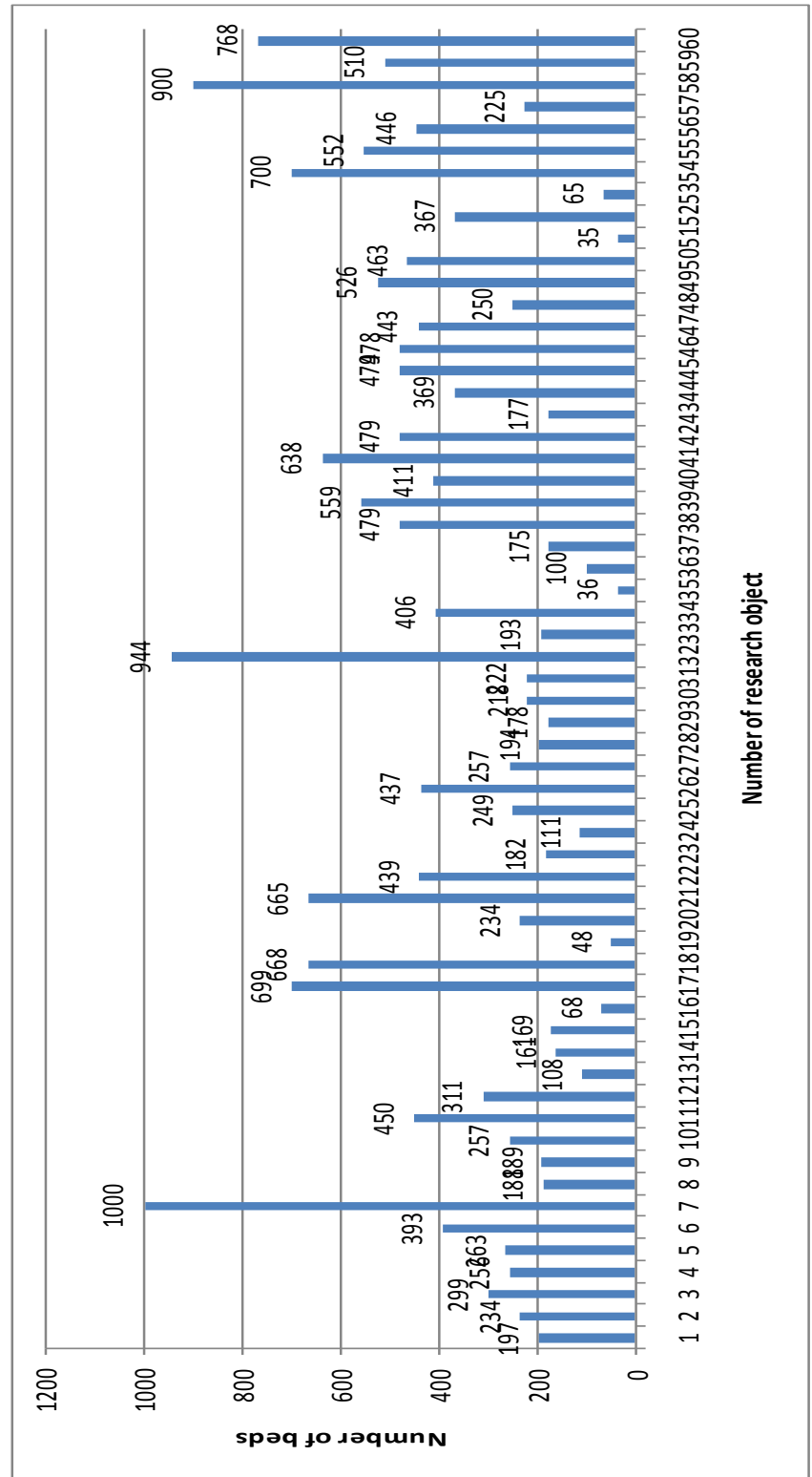

Fig. 6. Number of beds in research objects. 
In the figure 5 was presented number of nurses in tested hospitals in Poland. Figure 8.5 shows that highest number of nurses occurs again the 58 hospital (1060) and in the 59 hospital (127). In the figure 6 it was presented number of beds in tested hospitals. The highest number of beds possesses 58 hospital with III reference level (900) and 59 object (510). Presented data shows huge differences between nurses number in the tested hospitals. These differences are connected probably with the number of beds at hospitals.

Quality management (URBAN 2013, BORKOWSKI S., ROSAKSZYROCKA J. 2010) systems increasingly become a fast-growing economy, an essential tool in the pursuit of business and fight for the quality of goods and services. At the same time QA systems increased capacity to meet the identified needs of clients and potential entrepreneurs (OLKIEWICZ 2012).

Increasing interest in the implementation of quality management systems (KANOWNIK 2014, GŁÓD 2011). Despite the many difficulties occurring in the implementation of systems, an increasing number of health care institutions decide to not, for it is they become a bargaining chip, acting at the same time to open wider to the environment (GRÓCAWÓJTOWICZ 2009, LIEN, Wu, CHEN, WANG 2014).

The first step to improve the quality of health care in Poland, became a program of accreditation of hospitals according to national quality standards (KRot 2004, ŚwiątKo 2015, Rogala 2008, Czerw, RELIGIONI 2013). Table 1 shows the history of national accreditation programs in various countries in Europe. Table 1. The history of national accreditation programs in various countries in Europe (WWW.CMJ.ORG.PL; SZETELA 2012, PANDI, PARANITHARAN, JEYATHILAGAR 2016). 
Table 1. The history of national accreditation programs in various countries in Europe

\begin{tabular}{|l|l|}
\hline Year & \multicolumn{1}{|c|}{ Nation } \\
\hline 1990 & Great Britain \\
\hline 1995 & Finland \\
\hline 1996 & Spain \\
\hline 1997 & Czech Republic \\
\hline 1998 & Poland, Switzerland \\
\hline 1999 & $\begin{array}{l}\text { France, Lithuania, the } \\
\text { Netherlands, Italy }\end{array}$ \\
\hline 2000 & Portugal \\
\hline 2001 & Germany, Bulgaria \\
\hline 2002 & $\begin{array}{l}\text { Denmark, Ireland , Italy }, \\
\text { Kyrgyzstan }\end{array}$ \\
\hline 2003 & Bosnia \\
\hline 2004 & Croatia \\
\hline 2005 & Albania \\
\hline
\end{tabular}

Source: WWW.CMJ.ORG.PL; SZETELA 2012, PANDI, PARANITHARAN, JEYATHILAGAR 2016

Today, in every developed country is functioning at least one organization dedicated to the promotion and evaluation of the quality of the health care organization (Table 2).

With time Accreditation proved to be insufficient and started to reach for a tool to improve the overall functioning of the institutions, and internationally recognized, which are ISO standards (MICHALAK 2013, Shaw, Bruneau, Kutryba, SunOl 2010). In 1979. established the first civilian standard quality. It was the British standard BS 5750 Specification for design / development, production, installation and servicing. It was developed based on the requirements of the US military standards (FrĄCZKIEWICZ-WRONKA, AUSTEN 2013). This was an organization set goals and how to monitor their implementation (ROSAKSZYROCKA 2015). It has also become the basis for the first edition of the 
ISO 9000 series of quality assurance systems. Requirements, Issued for the first time in 1987 (Davies 2000). These standards were subsequently amended in 1994, 2000 and 2008 (OLKIEWICZ 2012, BORYS, ROGALA, SKOWRON 2015).

Table 2. The development of national accreditation programs in Europe

\begin{tabular}{|l|c|}
\hline \multicolumn{1}{|c|}{ Nation } & Organization name \\
\hline $\begin{array}{l}\text { Czech } \\
\text { Republic }\end{array}$ & Spojena areditac ${ }^{\text {nıkomise }}$ \\
\hline Denmark & Danish Healthcare QualityProgramme \\
\hline Finland & Social and Health Quality Service \\
\hline France & HautAutorite' de Santé \\
\hline Germany & Transparenz und Qualitä̈imGesundheitswesen \\
\hline Hungary & Institute for Healthcare Quality Improvement \\
\hline Ireland & Health Information and Quality Authority \\
\hline Lithuania & Accreditation programme for health care institutions \\
\hline Netherlands & NederlandsInstituutvoorAccreditatie van Ziekenhuizen \\
\hline Switzerland & Sana CERT Suisse \\
\hline Great Britain & Healthcare Accreditation\&Quality Union \\
\hline
\end{tabular}

Source: Shaw C. , Bruneau C., Kutryba B., Sunol G.R. 2010

There are the following quality systems:

1. Quality systems, to which belongs (GRÓCA-WÓJTOWICZ 2009):

- accreditation,

- ISO 9001 -(quality management system)

- ISO 17025 -(General requirements for the competence of testing and calibration laboratories)

- ISO 15189 (medical laboratories - Specific requirements for quality and competence)

- ISO 13485 (requirements for manufacturers of medical devices medical devices must meet legal standards and customer expectations). 
2. Safety systems, which belongs to:

- OHSAS/PN-N 18001,

- BS 7799,

- ISO 27001,

- ISO 22000,

- HACCP.

3. Branch systems, which belongs to:

- accreditation,

- ISO 15189,

- ISO 13485.

4. Universal systems, which belongs to:

- ISO 9001,

- ISO 14001,

- OHSAS/PN-N 18001,

- BS 7799,

- ISO/IEC 27001,

- ISO 17025 .

5. Management systems, which belongs to:

- ISO 9001,

- ISO 14001,

- OHSAS/PN-N 18001,

- BS 7799,

- ISO 27001,

- ISO 13485,

- ISO 22000

6. Products/services systems, which belongs to:

- ISO 17025,

- ISO 15189.

7. Systems of man process:

- accreditation,

- ISO 17025 ,

- ISO 15189,

- ISO 13485, 
- ISO 9001,

- ISO 14001,

- OHSAS/PN-N 18001,

- BS 7799,

- ISO 27001.

8. Auxiliary processs' systems:

- HACCP,

- ISO 22000.

\section{Conclusion}

Results and analysis has shown that having a quality management system by the surveyed hospitals in Poland, positive impact on the assessment of patients' satisfaction with the quality of medical services. It was found that the quality systems ensure the improvement of the quality and safety of medical services, as well as provide greater predictability and stabilization of the processes (ZIMON 2016, ULEWICZ 2013), are becoming increasingly strategic goal of each entity medical.

One aspect of increasing competitiveness is to ensure that the facility an appropriate level of service quality, based on the concept of quality management, which allows you to not only increase patient satisfaction, but also contributes to the efficient management of the entity therapeutic and rational disposal of available human resources, in kind, cash and informative. The hospital will be competitive when the manager it will be to analyze the data on expenditures, the results, the efficiency of processes by comparing their performance with respect to existing and potential competitors on the market.

The concept of measuring the difference between expectations and perceptions in the form of the Servqual gap score proved very useful for assessing levels of service quality. Parasuraman argued that, with minor modification, Servqual can be adapted to any service organization. Information on service quality gaps can help managers diagnose where performance improvement can best be targeted. The largest negative gap, 
combined with assessment of where expectations are highest, facilitates prioritization of performance improvement. Equally, if gap scores in some aspects of service do turn out to be positive, implying expectations are actually not just being met but exceeded, then this allows managers to review whether they may be "over - supplying" this particular feature of the service and whether there is potential for redeployment of resources into features which are under performing (TAZREEN, 2012).

\section{Bibliography}

1. BORKOWSKI S., ROSAK-SZYROCKA J. 2012. Jakość i satysfakcja w ustugach medycznych, Wydawnictwo PTM, Warszawa.

2. BORKOWSKI S., ROSAK-SZYROCKA J. 2010. Jakość ustug medycznych w Polsce, Wydawnictwo TPM.

3. BORYS T., ROGAla P., SKOWRON P. 2015. Zrównoważony rozwój organizacji - odpowiedzialne zarządzanie, Wydawnictwo Uniwersytetu Ekonomicznego we Wrocławiu, Wrocław.

4. CZERW A., ReLIGIONI U. 2013. Wdrażanie systemu zarządzania jakościa w budowaniu przewagi konkurencyjnej podmiotów świadczacych działalność lecznicza, „Ekonomia i Prawo”, Polszakiewicz B., Boehlke J. (red.), Tom XII, nr 2.

5. DAVIES H.T.O. 2000. Organizational culture and quality of health care, Qual Health Care, 9.

6. FRACZKIEWICZ-WRONKA A., AUSTEN A. 2011. Wyzwania nowego zarzadzania publicznego dla menedżerów $w$ ochronie zdrowia. Wyniki badań empirycznych, "Zarządzanie Zasobami Ludzkimi", nr 2 (79), s. 9-28.

7. GŁÓD G. 1996. Zarządzanie zmiana $w$ jednostce ochrony zdrowia, Wyd. Uniwersytetu Ekonomicznego w Katowicach, Katowice 2011, s. 13, [w:] J. Skalik: Projektowanie organizacji instytucji, Wyd. Akademii Ekonomicznej, Wrocław.

8. GRÓCA-WOJTOWICZ P. 2009. Systemy jakości i bezpieczeństwa w jednostce sektora ochrony zdrowia, „Problemy Jakości” nr 8.

9. JANUSZ S. 2003. Zarzadzanie zasobami ludzkimi. Pracownicy $i$ nowe możliwości, Szpital Polski s. 33-36.

10. JURKOWSKI R. 2002. Racjonalizacja zarzadzania zasobami ludzkimi $w$ zakładach opieki zdrowotnej, Nowoczesne zarządzanie w opiece zdrowotnej, instrumenty zarządzania zakładami opieki zdrowotnej praca 
zbiorowa pod redakcją M. Trockiego., Instytut Przedsiębiorczości i Samorządności, Warszawa, ISBN 83 - 88432 - 16 - 8.

11. KANOWNIK G. 2014. Koncepcje zarządzania jakościa w stużbie zdrowia, Edukacja ekonomistów i menedżerów 4 (34).

12. KANOWNIK G. 2014. Koncepcje zarządzania jakościa w stużbie zdrowia, Edukacja ekonomistów i menedżerów 4 (34).

13. KROT K. 2004. Proces doskonalenia jakości $w$ placówkach opiekli zdrowotnej, „Problemy Jakości” nr 1.

14. LEWANDOWSKI R., KAUTSCH M. 2009. Rynek certyfikacji placówek ochrony zdrowia w Polsce, „Problemy Jakości” nr 4.

15. LIEN CH. H., WU J.J., CHEN Y. H., WANG CH. J. 2014. Trust transfer and effect of service quality on trust in the healthcare industry "Managing Service Quality", $\mathrm{nr} 4$.

16. MichalAK J. 2013. Czy system ochrony zdrowia może być efektywny, [red. nauk.] Frączkiewicz-Wronka A.: Efektywność zarządzania organizacjami publicznymi i jej pomiar, „Studia Ekonomiczne. Zeszyty Naukowe Wydziałowe Uniwersytetu Ekonomicznego w Katowicach”, nr 168.

17. OlKIEWICZ M. 2012. Ocena efektów funkcjonowania systemu zarządzania jakościa w przedsiębiorstwie, [w:] „Zarządzanie i Finanse”, R. 10, nr 3, cz. 1.

18. OLKIEWICZ M. 2012. Ocena efektów funkcjonowania systemu zarządzania jakościa w przedsiębiorstwie, W: Zarządzanie i Finanse. -R. 10, nr 3, cz. 1.

19. PANDI, A. P., PARANithaRAN, K.P., JeYATHILAGAR, D. Implementation of IEQMS model in engineering educational institutions - a structural equation modelling approach, Total Quality Management and Business Excellence, ISSN 1478-3363.

20. Rogala P. 2008. Najważniejsze wyniki badań przeprowadzonych przez ISO, „Problemy Jakości” nr 2.

21. RoSAK-SZYROCKA J. 2015. Systemy jakości w aspekcie jakości usług medycznych szpitali w Polsce, „ABC Jakości”, 3.

22. ROSAK-SZYROCKA J., BORKOWSKI S. 2007. The Influence of Resources on the Quality of Medical Services from the Workers of the Health Care in Poland Perspective. Human Resources Management and Ergonomics, 1.

23. Shaw C., Bruneau C., KutryBa B., Sunol G. B. 2010. Towards hospital standardization in Europe, International Journal for Quality in Health Care Advance Access published June 24.

24. Shaw C., Bruneau C., Kutryba B., SunOl G. R. 2010. Towards hospital standardization in Europe, "International Journal for Quality in Health Care Advance Access" published June 24. 
25. SzETELA A. 2012. Zewnętrzne metody oceny jakości $w$ ochronie zdrowia akredytacja $i$ system zarządzania jakościa wedtug normy ISO 9001:2008, „Problemy Zarządzania”, vol. 10 nr 2 (37).

26. ŚWIĄTKO D. 2015. Polskie wyroby medyczne zdobywają zagraniczne rynki, „Jakość” nr 2.

27. UlEWICZ R. 2013. Effectiveness Assessment of Functioning of Quality Assurance System, Production Engineering Archives, 1.

28. URBAN W. 2013. Jakość ustug $w$ perspektywie klientów i organizacji $w$ kierunku zintegrowanej metodyki pomiaru, Oficyna Wydawnicza Politechniki Białostockiej, Białystok.

29. www.cmj.org.pl

30. ZIMON D. 2016. Influence of quality management system on improving processes in small and medium-sized organizations, Quality - Access to Success, ISSN 1582-2559.

31.TAZREEn S. 2012. An Empirical Study of Servqual as a Tool for Service Quality Measurement. Journal of Business and Management, Volume 1, Issue 5 . 